\title{
LEIGH HUNT'S LONDON JOURNAL
}

\author{
By Leslie A. Marchand
}

Dr. Marchand, a member of the Department of English, is the author of The Athenaeum: A Mirror of Victorian Culture, a volume in which he has told the history of one of the most notable of all the English literary magazines of the Nineteenth Century. In the following article he gives an account of $a$ short-lived but interesting contemporary of the Athenaeum.

7 URNING over the leaves of Leigh Hunt's London Journal is an experience that can open the pages of the past more realistically than can the perusal of any social or literary history of Pre-Victorian England. That experience may fortunately be had in the Rutgers University Library which has recently acquired a complete set of the 9 I numbers and all the monthly supplements of this interesting weekly periodical which began April 2, I834, and ended abruptly on December 26, I 835. Since he started The Examiner in 1808 , Hunt had had experience in many periodical adventures -The Reflector, The Indicator, The Liberal (aided and abetted by Byron), The Companion, The Chat of the Week, The Tatler- ${ }^{1}$ and he had learned something of the tastes and interests of his audience. Personal and familiar as is the editorial tone of the London Journal, Hunt put more variety into it than into some of his other periodicals, albeit less original material graced its pages. Having less impulse to lèse majesté and perhaps less desire for martyrdom than in his Examiner days when he was jailed for calling the Prince Regent "a libertine over head and ears in disgrace," he eschewed politics and went in for "improvement" and the spread of knowledge in pleasant doses to the "penny public."

In the address to his readers in the first number he stated his purpose clearly:

The object of this publication, which is devoted entirely to subjects of miscellaneous interest, unconnected with politics, is to supply the lovers of knowledge with an English Weekly Paper, similar in point of size and variety, to Chambers's Edinburgh Journal, but with a character a little more southern and literary.

1 The Examiner, 1808-1821; The Reflector, 1810-1811; The Indicator, 1819-1821; The Liberal, 1822-1823; The Companion, 1828; The Chat of the Week, 1830; The Tattler, $1830-1832$. 
Although Hunt didn't expect to achieve the large circulation of Chambers's nor that of the Penny Magazine, which, with the advantage of being subsidized by the Society for the Diffusion of Useful Knowledge, had built up a circulation of more than a hundred thousand, yet he felt that with all the growth of periodical literature there were still some gaps in the supplies to the public intellect. One of these gaps which he hoped the London Journal would fill he described as "consisting in a want of something more connected with the ornamental part of utility, - with the art of extracting pleasurable ideas from the commonest objects, and the participations of a scholarly experience." He hoped to reach the "thousands of improving and inquiring minds" in the metropolis.

With this end in view it was proposed that the London Journal should consist of

One Original Paper or Essay every week, from the pen of the Editor; of matter combining entertainment with information, selected by him in the course of his reading, both old and new; of a weekly abstract of some popular or otherwise interesting book, the spirit of which will be given entire . . .; and, lastly, of a brief current notice of the Existing State of Poetry, Painting, and Music, and a general sprinkle of Notes, Verses, Miscellaneous Paragraphs, and other helps to pleasant and companionable perusal.

In fact, during its brief existence the London Journal did give its readers all that Hunt promised and more, and it did chart a way and fill a gap between the wholly utilitarian and non-literary penny magazines on the one hand, and the more sedate literary journals on the other. To show the good feeling existing among these pre-Victorian "improvers" one might point to the letter from Robert Chambers printed in the fourth number of the London Journal commending Hunt's effort but taking exception to his claim to be the "originator of cheap respectable publications," which distinction Chambers reserved for his elder brother. Hunt added a polite rebuttal, saying that "the appearance of the Tatler was antecedent to that of the Edinburgh Journal, and that in the Indicator, and in the Tatler also, (if we recollect rightly), we professed a wish to extend an acquaintance with matters of intellectual refinement among the uneducated." And Hunt added a generous note of praise for another contemporary which had tried to reach the masses without stooping except in price: "We take this opportunity of observing, that among the foremost, if not the very first, to lower the price of respectable periodical literature, 
though not professedly to extend it to those who have missed a classical education, was the Athenaeum."

When Leigh Hunt's London Journal began on April 2, I 834, it was a Wednesday publication, price three halfpence. Like most of the weekly periodicals of the time it had three columns of fine print, and throughout its existence it consisted of eight folio pages. For the convenience of country readers it was also bound in monthly parts. The publisher at first was "H. Hooper, I3, Pall Mall East," and the printer, "Sparrow, I I , Crane Court." Within a few months, however, evidence of the progress of the new machine age is given in the line at the bottom of the first page: "From the Steam-Press of C.\&.W. Reynell, Little Pultney Street." Nine monthly supplements, each of eight pages, appeared in 1834 , containing a serial on "The Streets of the Metropolis, their memoirs and great men," a work which must have involved much research on the part of the editor. After the first number the whole of the back page was given to advertisements, mostly of book publishers, though occasionally also of such ingenious mechanical inventions as "Self-acting Portable Water Closets." But the advertisements disappeared entirely with Number 20 (August I 3, I 834), leaving more room for "improvements." The first volume concluded with Number 40, December 3 I, 1834 .

On June 6, I 835, a merger was made with Charles Knight's The Printing Machine, and the new periodical became Leigh Hunt's London Journal and The Printing Machine, the price being increased to twopence and the publication date changed to Saturday. The format and the number of pages remained the same. Each of the combining periodicals kept its original character, three or four of the eight pages being given to The Printing Machine, which followed the London Journal under its own title and consisted solely of book reviews. Charles Knight, editor and printer of the successful Penny Magazine as well as of The Printing Machine, probably bolstered the tottering finances of the London Journal. ${ }^{2}$ Knight became the publisher and Leigh Hunt continued as editor. The monthly supplement was taken up again on June 30 and continued "The Streets of the Metropolis" and gave some extra reviews for The Printing Machine.

2 There is no way of telling exactly what the circulation was, though it was probably not more than a few thousand. Many sixpenny periodicals at the time lived on a circulation of two or three thousand. The low price may have encouraged a wider sale for the London Journal, however. The $A$ thenaeum had increased its circulation six fold (to about 18,000 ) by lowering the price from $8 \mathrm{~d}$. to $4 \mathrm{~d}$. 
The bulk of the Journal from the beginning consisted not of miscellaneous original articles or stories such as we would expect in a periodical of general interest today, but of regular features and series under the same headings week after week. The first page was usually given over to an informal essay by the editor. The tone of these essays is familiar to the readers of Hunt: sympathetic, whimsical, confessional, and warmly human. Second only to Lamb in taking common daily experience and investing it with glowing significance, Hunt delighted in subjects like "Breakfast in Summer," or "Tea-drinking," or " 'A Now,' Descriptive of a Cold Day," and when he embarked upon such a subject his readers got much more than their three ha'penny or twopence worth.

Four or five series of regular features filled the greater part of the remaining pages. In making up these, Hunt used scissors and paste a great deal, but many of them involved considerable research on the part of the editor nevertheless. There was the "Letter to such of the Lovers of Knowledge as have not had a Classical Education," consisting of popularizations of classic writers, of Greek mythology, and so forth. "The Week" consisted of informative and chatty comment on matters appropriate to the season-on the birds, on cricket, on folk-lore and history-with copious quotations from books, the general tone being that of the Society for the Diffusion of Useful Knowledge, "improvement" with a sugar coating. A regular feature in the first six numbers was called simply "The London Journal." It told what was going on in the world of books, pictures, operas, music, "sometimes as persons present, sometimes as mere recorders of the leading opinions of the town." It was meant for country readers who would like to know "a little of what is going forward, on points interesting to the advancement of knowledge." Paganini, who was then the god of the London musical season, several times received honorable mention in the paragraphs of this section. No praise was too high for him "and his marvelous violin which is now to be heard at the Adelphi, glorying, praying, laughing, lamenting, making love."

The longest-running of all the feature series in the Journal, and perhaps the most congenial to its editor, was that called "Romances of Real Life," which began in the first number and continued throughout the life of the magazine. Like most of the material except Hunt's initial essay in each issue, it was not original but derivative, though displaying much ingenuity of selection and presentation. 
"Table Talk," later gathered into a volume by Hunt, consisted of miscellaneous tid-bits from literature and general knowledge, not unlike what we are now accustomed to seeing in the short end paragraphs in the Reader's Digest-anecdotes from letters, journals, or memoirs, or Disraeli's Curiosities of Literature, and sometimes popularized natural history from the Penny Magazine and Chambers' Cyclopedia. This feature ran pretty regularly from the second number, and there was added later "Hints for Table Talk" from correspondents.

As Hunt had promised, he gave abstracts of novels and other books of current interest, one in every issue. These later developed into reviews of a sort with lengthy extracts. Except in the journals of high literary pretension, book reviews in those days were little more than this-extracts spliced together with a little introductory matter or a few transition summaries. This is not the ideal of criticism, but unless the reviewer has special qualifications for the critical evaluation of the book under consideration, there is much to be said for the method; at least it permits the author to speak for himself more effectively than in the garbled paraphrase of an incompetent reviewer. Book reviewing as such, however, was not a regular feature of the journal until it combined with The Printing Machine.

Beginning with number I 5, "Specimens of Celebrated Authors" was a frequent feature. Hunt's own interests and tastes are displayed in the selections: Montaigne, Cowley, Swift, Goethe, Jean Paul Richter, St. Evremond, Addison, Voiture, Jean Balzac (a seventeenth century French writer who was a favorite and correspondent of Richelieu). A companion feature, "Characteristic Specimens of the English Poets," never got beyond Chaucer, who was presented with enthusiastic comments and explanations for the layman interspersed with copious quotations from a Mr. Clarke's The Riches of Chaucer, "in which the spelling is modernized, and the old pronunciation. marked with accents, so as to show the smoothness of the versification."

Toward the end of 1834 special departments of Fine Arts and Music were set up, at least in name, but the work of the editor was already too great to permit a thorough covering of exhibitions and concerts. It is not surprising that the editor of a one-man periodical should fall back on second hand reports and reviews of books in the respective fields. 
Perhaps the most interesting feature of the Journal to the modern reader is the attention given to contemporary writers and books which have lasted in literary history. Following the death of Lamb in I 834, not only did the London Journal give an obituary notice but it also printed an "Autobiographical Sketch," "Personal Recollections," running through four numbers, and "Specimens and Criticism," continued through six numbers. In the second volume ( I 835) Hazlitt's Characters of Shakespeare's Plays (republished from the second edition) ran serially until complete.

Hunt rightly prided himself on being of that small band who treasured the memory and the poetry of Keats during the period of twenty-five years or more after his death when he was either entirely unknown or misunderstood and derided by critics who took their cue from the unfair personal attacks in the Quarterly Review and Blackwood's during Keats's lifetime. Hunt's presentation of "The Eve of St. Agnes,"- in more than three pages of a leading article on January $2 \mathrm{I}, \mathrm{I} 835$, with a running comment of praise and explanation, was a notable contribution to the reestablishment of the reputation of the forgotten poet. It is the best kind of appreciative criticism; one feels the communicable glow of personal enthusiasm of one of the earliest friends and champions of Keats.

Hunt was generally acute in discovering, and generous in praising, new talent which arose in his own day. One of the most extensive and most sympathetic and understanding reviews of Browning's Paracelsus appeared in the London Journal of November 21, I835, taking the whole of the three and a half pages of the Printing Machine section. Other books noticed or reviewed at length in I 835 included Coleridge's Table Talk, Longfellow's Outre-Mer, and Willis's Pencillings by the Way.

Altogether Hunt gave a great deal for the money. Although much of the material was of necessity derived from the reading of the editor, his reading was wide, his taste good, his selections wisely chosen and interestingly presented. The magazine was neither dull nor shoddy. Hunt felt his responsibility towards his readers and never padded out the journal indiscriminately merely for the sake of filling space. The weaknesses were those inherent in a one-man periodical. (Hunt had almost no aid except a few compositions by a promising young man named Egerton Webbe, a poem or two from Landor, and a few paragraphs from "Correspondents.") In spite 
of his attempt at variety, there was an inevitable sameness of tone, and that tone was possibly a little high for his three halfpence or twopenny readers. With all his efforts to sugarcoat and popularize, Hunt himself was too sensitive to subtleties and too literary for readers whose level was more nearly struck by the matter-of-fact Penny Magazine, and the utilitarian Chambers's Edinburgh Journal. The sheer labor of editing must have contributed as much as the financial instability of Hunt's journal to its demise at the end of I 835 .

But for a reader of literary and general cultural interests today, Leigh Hunt's London Journal is still good reading. Hunt himself recorded in his Autobiography (written in 1850 ) that the bound volumes were then "in request, I understand, as a book for seavoyages; and assuredly its large, triple columned, eight hundred pages, full of cheerful ethics, of reviews, anecdotes, legends, tabletalk, and romances of real life, make a reasonable sort of library for a voyage. . .." 